\title{
The Inhibitory Action of Capparisspinosa Leaves Against the Tumor and Leishmania
}

\author{
Nidal M.S. Al-Janabi ${ }^{1 *}$, Mohammad M. F.Al-Halbosiy ${ }^{2}$ and Samah. R. H. Al-Badri ${ }^{3}$ \\ ${ }^{1}$ Department of Food Science, Agriculture College, Baghdad University, Iraq \\ ${ }^{2}$ Medical and Molecular Biotechnology Department / Biotechnology Research Center, Al-Nahrain \\ University, Iraq \\ ${ }^{3}$ Ministry of Agriculture, Iraq \\ *Corresponding Author: nidhalspring@yahoo.com
}

\begin{abstract}
The leaves of the Capparisspinosa were collected from the eastern Radwaniya/Baghdad duringthe months April, May, June, July, September, and September. The leaves were extracted by water and alcohol.

The effectiveness of anti-tumor and anti-leishmania for the water and alcohol extracts of alQabar leaf samples for May and September, which were characterized by the highest percentage of active compounds for the rest of the tested months, was evaluated by adopting the results of a previous study for the same researchers or chemical composition and leaf content of active compounds The concentrations of $250,500,1000 \mathrm{mg} . \mathrm{L}^{-1}$ were evaluated for anti-tumor efficacy. The anti-leishmania efficacy was tested at 250,500 and $1000 \mathrm{mg} \mathrm{L}^{-1}$. The sample of the alcohol extract for May collected complex showed the highest anti-tumor activity at $63.5 \%$ at 500 mg. $\mathrm{L}^{-1}$ and the highest efficacy of the samples of alcohol extract for September was $56.1 \%$ at the concentration of $250 \mathrm{mg} . \mathrm{L}^{-1}$, while the water extract for the May sample did not show any effectiveness even at the highest concentration $1000 \mathrm{mg} \mathrm{L}^{-1}$, but the September collected sample was effective at $49.3 \%$ In the case of the inhibitory efficacy of leishmania, the alcohol extract of the May sample did not show on inhibitory activity at the lowest concentration. The effectiveness of $41.3 \%$ was observed at $500 \mathrm{mg} . \mathrm{L}^{-1}$, but decreased to $14.8 \%$ at the highest concentration of $1000 \mathrm{mg}$ $\mathrm{L}^{-1}$. Of the same month at the lowest concentration of $37.8 \%$ and decreased effectiveness there was an increase in the anti-leishmania effect of the September extract of the sample with increased concentration. There was of its effectiveness at the lowest concentration of a user and then reached 8 and $37 \%$ at the concentration of 500 and $1000 \mathrm{mg} . \mathrm{L}^{-1}$ with the same percentage, and the water extract for the September sample did not show any efficacy at the minimum and highest concentrations, except the concentration of $500 \mathrm{mg} . \mathrm{L}^{-1}$, which reached $11 \%$.
\end{abstract}

[DOI: 10.22401/ANJS.00.2.08]

Keywords: Capparisspinosa, Anti-tumor, anti- leishmania.

\section{Introduction}

Capparisspinosa is a major cultivar of Capparis [11]. Known in Iraq as Shafallah and Kabar in Basra, kifri in Kurdistan [4].

Previous studies have indicated the presence of active compounds in C.spinosa such as alkaloids, lipids, flavonoids and clocosinols [5]. They have a number of biological agents such as antifungal, antifungal and liver toxicity [15].

There have been numerous studies on the original habitat of the plant. Some pointed out that the island of Capri, off the coast of Naples, derived from the name of the plant, while other studies indicate that the plant origin dates back more than 7500 years before the date by finding the plant seeds in the socalled In Iraq, and other studies have suggested that the original inhabitants of the plant are Mediterranean countries [16].

The vast majority of herbaceous plants used in conventional medical treatments are obtained from the wild rather than cultivated by C.spinosa, which is one of the most highly valuable medicinal and medicinal plants in a different system of medicines. Greece and China [3].

Cancer is the second most common disease after heart disease and is a leading cause of death worldwide. It has been found 
that some nutrients and some non-food compounds have the direct effect of preventing some chronic diseases such as obesity, heart disease and cancer. In one way or another with the type of food intake, if 80$90 \%$ of cancers are due to environmental factors, $35 \%$ of these factors are due to the quality of the food intake [14]. Recent studies have shown that phytochemicals exert anticancer effects by altering various activities (Kinases Tyrosine) Receptor in the expression of genes responsible for cell proliferation and apoptosis [11].

The genus C.spinosa has received a lot of publicity recently, because it is the source of the most active biologically active ingredients, which has a wide range of biological properties, has attracted the attention of the routine as a food component, and the results of clinical studies indicated its potential role in the anti-carcinogenic effect [19].

Al-Daraji M. N. in [1] concluded that the raw water extract of C.spinosa leaves had an effect on the growth of hep-2 and hepatocellular carcinoma cells in a low concentration of $125 \mu \mathrm{g} / \mathrm{mL}$. Hep- 20.340 cell density $\%$, Hela $0.6545 \%$, and the highest inhibitory effect of the extract at $1000 \mu \mathrm{g} / \mathrm{mL}$.

Selenium is found at a high concentration in the plant, compared to its concentration in other plants, which is associated with the prevention of certain forms of cancer [18].

Leishmania is a genus of single-cell parasites involving more than thirty species that prey on vertebrates, primarily on mammals, and leishmaniasis can be caused by 20 different species of leishmaniasis and has a wide range of clinical symptoms ranging from ulcers to self-healing The skin of cutaneous leishmaniasis (CL) to the nasopharyngeal larynx (mucosal mucous leishmaniasis) and diffuse visceral leishmaniasis (VL) is known as leishmaniasis. These parasites are transmitted by female bites of the sand fly Phlebotomuspapatasi (Scopoli) [7].

The World Health Organization (WHO) has reported that there are approximately 12 million cases of leishmaniasis worldwide, with 2 million new cases of self-healing lesions of leishmaniasis and half a million new cases of visceral diffuse leishmaniasis in one year [7].

Jacobson, R.L.; Schlein, Y. in [10] note that C.spinosa is a control of leishmaniasis, which helps to control major leishmaniasis, and has introduced several medicinal activities of the aquatic extracts of elder plants, including the control of leishmaniasis [10].

Extracts of different parts of C.spinosa have been found to have a biological activity against a large number of pathogens, Antileishmania and anti-allergic activities [17].

\section{Materials and Methods Extraction:}

Samples collected: The May and September samples were collected and extracted according to [20].

\section{Antitumor activity:}

Antitumor efficacy of aqueous and alcohol extract of leaves for May and September was evaluated against the L20B cell line derived from murine fibroblast. The 3-(4,5-dimethylthiazal-z-yl)-2,5-diphenylterazolium (MTT), in which the vitality of the cells is measured in a chromatic manner according to [8]. Briefly, add $100 \mu \mathrm{l}$ of L20B per hole with $10^{6}$ cells $/ \mathrm{ml}$ ) was cultured in96-well tissue culture plate. Different concentrations of the leaf extract were prepared $(500,250$ and $1000 \mathrm{mg} / \mathrm{mL})$ by dissolving it with water, taking $100 \mu \mathrm{l}$ of concentrations was added to each well and placed in the incubator $37{ }^{\circ} \mathrm{C}$ for 24 hours. After the end of the incubation,

10 microliters of MTT dye was added at a concentration of $5 \mathrm{mg} / \mathrm{ml}$ to each well and incubated at $37{ }^{\circ} \mathrm{C}$ for 4 hours. Finally add 50 $\mu \mathrm{l}$ of Dimethylsulfoxide (DMSO) solution to each well and leave for $10 \mathrm{~min}$. L20B cells with the whole medium without the extraction solution as a positive comparison. The whole medium without cells and the extraction solution is a blank solution, whereas the absorbance was measured at 620 nanometers per well and using the Elisa Enzyme Linked Immunosorbent Assay technique. The percentage of vitality and inhibition of living cells was calculated as follows: 
Inhibition $\%=$ Optical density for positive comparison - Optical density of the model/optical density for positive comparison $\times 100$.

\section{Antileishmanial activity:}

The effect of anti-leishmania on the water and alcohol extract of the leaves of the alKabir plant for May and September was estimated against the promastigote forms of L.tropica. The MTT test is a chromatic test of cell vitality as described by [13], $(100 \mu \mathrm{l})$ of the promastigote form cells in a single well $\left(10^{6}\right.$ cells $\left./ \mathrm{ml}\right)$ seeding in 96-well tissue culture plate. The different concentrations of the extraction solution (500, 250 and 1000) $\mathrm{mg} / \mathrm{ml}$, which were prepared from the solubility of $3 \mathrm{~g}$ of the extract of leaves of dried fruit plant in $3 \mathrm{ml}$ of water, was added on the well plate.Then, Plate was incubated at $26{ }^{\circ} \mathrm{C}$ for 24 hours and after the incubation period, $10 \mu \mathrm{l}$ of dye MTT at $5 \mathrm{mg} / \mathrm{mL}$ concentration was added per well and incubated at $26{ }^{\circ} \mathrm{C}$ for 4 hours. Finally, $50 \mu \mathrm{l}$ of DMSO was added to each well and incubated for $10 \mathrm{~min}$. The promastigote forms cultured in a complete medium without extract. The whole medium without the promastigoteforms and the macromolecule extract was used as blank. The absorbance was measured at 620 nanometers per well and Elisa (Enzyme Linked Immunosorbent Assay).The percentage of vitality and inhibition of living cells was calculated as follows:

Inhibition $\%=$ Optical density for positive comparison - Optical density of the model/optical density for positive comparison $\times 100$.

\section{Results and discussion \\ Antitumor efficacy:}

Table (1) shows the percentage of inhibition of cancer cells derived from fibroblast cell-2 (cell murine fibroblast) cells using water and alcohol extracts of the leaves of the large plant for May and September.

The highest percentage of inhibition was due to the alcoholic extract for May at a concentration of $500 \mathrm{mg} / \mathrm{ml}$ which was
63.5\%. The water extract for the same month did not show any inhibitory activity at the tested concentrations.

It is also noted that the percentage of inhibition of water and alcohol extracts of the leaves of the Al-Kabir plant for May was less than the water and alcohol extracts for September, except for the alcohol extract for May at a concentration of 500 and 1000 $\mathrm{mg} / \mathrm{ml}$. Inhibition of water extracts for September (38.7, 45.1 and 49.3)\% concentration $(250,500$ and $1000 \mathrm{mg} / \mathrm{ml})$, and for alcoholic extracts for the same month (56.1, 44.2 and 33.4\%) at the same concentration respectively. In May, water extracts were (5.5, 16.28 and 0\%) respectively, and 50.9\%, 63.5, 52.29\%) respectively for alcoholic extracts with the same concentrations.

We conclude that the alcoholic extracts of the months of May and September were more effective than the water extracts for the two months mentioned. The effectiveness of anti-cancer extracts of the leaves of the plant of watercress and alcoholic water because it contains a number of active compounds. The sex of C.spinosa much of the publicity recently, because it is the source of most important components biological activity such as routine, which possesses a wide range of biological properties, and the results of clinical studies indicated its potential role in an anti-carcinogenic protective effect [19]. Both routine and isothiocyanate showed anticancer effects [6]. 
Table (1)

Percentage of inhibition of cancer cells with water and alcohol extracts of leaves of Al-Kabir plant for May and September

\begin{tabular}{||c|c|c|c|c||}
\hline \multirow{2}{*}{$\begin{array}{c}\text { Concentration } \\
\text { MgL }^{-1}\end{array}$} & \multicolumn{4}{|c||}{ Percentage of inhibition \% } \\
\cline { 2 - 5 } & \multicolumn{2}{|c|}{ The month of May } & \multicolumn{2}{c||}{ The month of September } \\
\cline { 2 - 5 } & Alcoholic Extract & Water extract & Alcoholic Extract & Water extract \\
\hline \hline 250 & 5.5 & 5.5 & 56.1 & 38.7 \\
\hline 500 & 16.28 & 16.28 & 44.2 & 45.1 \\
\hline 1000 & 0 & 0 & 33.4 & 49.3 \\
\hline
\end{tabular}

It may be due to the effect of the plant in the prevention of cancer to the presence of the element of selenium in which the concentration of high compared to its concentration in other plants and this element is related to the prevention of some forms of cancer [18]. The roots and leaves in the plant may have some antagonism [2]. Isothiocyanates (ITCc) has been paying great attention over the past years especially because of their strong anti-cancer properties that have been shown in the modelsboth in the laboratory and in vivo models [9].

\section{Anti-leishmanial activity:}

Table (2) shows the percentages of inhibition of L.tropica in water and alcohol extracts of the leaves of Al-Kabir plant for
May and September. The alcohol extract for May showed the highest inhibitory activity of $41.3 \%$ at $500 \mathrm{mg} / \mathrm{ml}$ followed by the water and alcohol extract of May The percentage of inhibitors for the water extract for the month of May was $37.8 \%$ with a concentration of $250 \mathrm{mg} / \mathrm{ml}$ and $37 \%$ for the September extract of $1000 \mathrm{mg} / \mathrm{ml}$ and $36.9 \%$ for the May water extract at a concentration of $500 \mathrm{mg} / \mathrm{ml}$. May and September at concentrate $1000 \mathrm{mg} / \mathrm{ml}$ for aqueous extract did not show him the effectiveness of inhibitory against Leishmania when the highest laboratory concentration, while the minimum concentration also did not show the effectiveness of inhibition of both extracts at September and at alcoholic extract at May.

Table (2)

Percentage of inhibition of leishmania (Baghdad bean) using water and alcohol extracts of leaves of al-Kabir plant for May and September

\begin{tabular}{|c|c|c|c|c||}
\hline \multirow{2}{*}{$\begin{array}{c}\text { Concentration } \\
\text { MgL }^{-1}\end{array}$} & \multicolumn{4}{|c||}{ Percentage of inhibition \% } \\
\cline { 2 - 5 } & Alcoholic Extract & Water extract & Alcoholic Extract & Water extract \\
\cline { 2 - 5 } & 0 & 37.8 & 0 & 0 \\
\hline \hline 250 & 41.3 & 36.9 & 8 & 11 \\
\hline 500 & 14.8 & 0 & 37 & 0 \\
\hline 1000 & & & & The month of September \\
\hline
\end{tabular}

This is confirmed by [12], where C.spinosa showed antifungal activity and leishmania and leukaemia because it contains cadabicine, betasitosterylglucoside-6'octadecanoate (1) and 3-methyl-2-butenylbeta-glucoside. In addition, extracts of the leaves of the large plant contain lacanin, which prevents the availability of sugars to parasites of Leishmania, leading to their aggregation [10].

\section{Conclusions}

Demonstration of the Prophecy of Antitumoractivity and Anti-leishmanial activity the water and alcohol extracts of the May and September samples. The highest 
Antitumor activity form of alcohol extracts of the May63.5\% of the Concentration $500 \mathrm{mg} /$ $\mathrm{ml}$ and $56.1 \%$ of the September samples of the Concentration $250 \mathrm{mg}$. $\mathrm{ml}^{-1}$. The alcohol extracts highest Anti-leishmanial activity form the May $41.3 \%$ of the Concentration 500 $\mathrm{mg} \mathrm{ml}^{-1}$.

\section{References}

[1] Al-Daraji, M. N. J.A., "Study of the inhibitory effect of the capar, Capparisspinosa L.aqueous crude leaf extract on the HEP-2 and HELA cancer cell line", Iraqi Journal of Desert Studies, 2(1): 67-73,2010.

[2] Arena, A.; Bisignano, G..andet al., "Antivieal and immunomodulatory effect of a lyophilized extract of Capparisspinosa L. buds",Phytother Res, 22: 313-317, 2008.

[3] Azaizeh, H.; Fulder, S.; Khalil, K.and Said, O. "Ethnomedicinal knowledge of local Arab practitioners in the Middle East Region", Fitoterapia, 74: 98-108, 2003.

[4] Blakeiock, R. A. and Townsend, C. C., Caapparidaceae., "Ministry of Agriculture and Agrarian Reform, Baghdad", Iraq. in C. C. Townsend and E. Guest, eds., Flora of Iraq, 4, (1):139145,1980 .

[5] Brevard, H.; Brambilla, M.; Chaintreau, A. and Marion, J.P., "Occurrence of elemental sulphur in capers (Capparisspinosa L.) and first investigation of the flavour profile", Flavour Fragrance J. 7: 313-321,1992.

[6] Cao,Y.L.;.Li, X. and et al., "Capparisspinosa protects against oxidative stress in systemic sclerosis demal fibroblasts". Arch Dermatol Res, 302(5): 349-355,(2010).

[7] Davis, A. J.; Kedzierskil, L., "Recent advances in antileishmanial drug development", CurrOpinInvestig Drugs 6: 163-169, 2005.

[8] Freshney, R. I., "Culture of Animal Cell", $6^{\text {th }}$ Edition. Wily-Liss, New York, 2010.

[9] Halkier, B. A. and Gershenzon, J., "Biology and Biochemistry of Glucosinolates, in Annual Review of Plant Biology”, (57): 303-33,2006.
[10] Jacobson, R.L.; Schlein, Y., "Lectins and toxins in the plant diet of Phlebotomuspapatasi (Diptera: Psychodidae) can kill Leishmania major promastigotes in the sandfly and in culture", Annals of Tropical Medicine and Parasitology,93 : 351-356,1999.

[11]Kan, Y. and Arslan, N., "Konya'dadoğalplarakyetisenkapari (Capparisovata Desf. var. canescens (coss.) Heywood) 'de bazıfenolojikvemorfolojiközelliklerüzerin ebirarastırma.

Bitkiselilaçmaddeleritoplantısı, Bildiriler" 29-31Mayıs. Eskisehir,.144148 (In Turkish),2002.

[12] Khanfar, M. A.; Sabri, S. S.; Zarga, M. H. and Zeller, K.P., "The chemical constituents of Capparisspinosa of Jordanian origin", . Nat Prod Res., 17:914, 2003.

[13] Mahmoudv, H.; Ezzatkhah, F., Sharififar, F. and et al., "Antileishmanial and cytotoxic effects of essential oil and methanolic extract of Myrtuscommunis" L. Korean J. Parasitol. 53(1),21-27,2015.

[14] Manjinder, K; Reinuka, M.; Rajesh, A.andChapla, A., "Grape Seed Extract Induces Cell Cycle Arrest and Apoptosis in Human Colon Carcinoma Cells Nutr Cancer" 60(1): 2-11,2008.

[15] Mouna, M.; Khadija, E.; Anass, E.; Abdellah, A.; Jamal, J. E.; Fouad, S.; Norddine, H. and Abdallah, B. "Capparis Spinosa $L$. promotes anti-inflammatory response in vitro through the control of cytokine gene expression in human peripheral blood mononuclear cells", 2016.

[16]Romeo, V.; Ziino, M. and Giuffrid, A. D., "Flavour profile of capers (Capparisspinosa L.) from the Eolian Archipelago by HS-SPME/GCMS", Food Chem. 101: 1272-1278,2007.

[17] Tesoriere, L.; Butera, D. and et al., "Bioactive components of caper (Capparisspinos L. from Sicily and antioxidant effects in a red meat simulated gastric digestion", Jagric Food Chem 55(21): 8465-8471, 2007. 
[18] Tlili, N; Munne-Bosch, S.; Nasri; N.; Saadaoui, E.; Khaldi, A. and Triki, S. J. "Food Lipids", 16: 452-464,2009.

[19] Webster, R. P.; Gawde, M. D. and Bhattacharya, R. K., "Protective effect of rutin, a flavonol glycoside, on the carcinogen-induced DNA damage and repair enzymes in rats", Cancer Letters. 109, 185-191, 1996.

[20]Zhou, X.; Peng, J.; Fan, G. and Wu, Y., "Isolation and purification of flavonoid glycosides from Trolliusledebouri using high-speed countercurrent Chromatograyphby stepwise increasing the flow-rate of the mobile phase", Journal of Chromatograyph A, (1092): 216-221, 200. 